This is the peer reviewed version of the following article: Hoffmann $\mathrm{C}$. Environmental determinism as Orientalism: The geo-political ecology of crisis in the Middle East. Journal of Historical Sociology 2018;31:94-104, which has been published in final form at

https://doi.org/10.1111/johs.12194. This article may be used for noncommercial purposes in accordance With Wiley Terms and Conditions for self-archiving. 


\section{Environmental Determinism as Orientalism: The Geo-Political Ecology of Crisis in the Middle East}

\section{Clemens Hoffmann, University of Stirling}

\section{Abstract}

From 'Resource Curse' to 'Climate Conflict', more and more analyses of the current crisis in the Middle East start their reasoning from geo-physical or natural conditions as determinants of social life. Paradoxically, despite its resource riches giving rise to conflict, the region's ecology is portrayed as fragile, alien and hostile. This part of an imperial oriental imagination, which assume that a scarce nature is mismanaged by societies and states overall incapable of negotiating modernity. This precarious, crisis driven environment is now pushed to the edge by the effects of climate change with looming desertification and weather extremes and a scramble for shrinking oil reserves threatening to make the region all but inhabitable, turning the region into a vicious cycle of conflict and environmental degradation. This article suggests that this environmental oriental determinism in Middle East can be overcome by entering political ecology into the register of historical sociological analysis. Re-socialising and historicising nature-society relations avoids reifying the Cartesian nature/society divide, offering historical sociology a better toolkit to navigate the current crisis. Vice versa, it argues that political ecology can benefit from recognising the role of geopolitical relations in the social reproduction nature.

\section{Introduction}

With the Syrian civil war in its sixth year, a debate has emerged on whether its origins are to blame on a drought that preceded the outbreak of the civil war. Rural resource scarcity resulting from the drought is thought to have contributed to rural-urban migration, swelling the ranks of the urban poor, eventually fuelling a revolutionary potential to the point that protests broke out (Gleick, 2014; Kelly et al., 2015). Climate change, thus, revealed the institutional inadequacies, as mirrored in policy debates on adaptive capacities and climate change resilience. Political causes for conflicts from Sudan to Syria are now overshadowed by debates about 'climate conflict' in those regions. Despite the obvious political dimension contributing to its outbreak, namely the ruthless oppression of popular unrest by the Assad regime in the wake of the Arab Spring, this argument finds a lot of popular uptake with policy makers, from UN representatives to Prince Charles (Selby and Hulme, 2015).

Apart from obscuring political culpability for the ongoing violent oppression, this argument is problematic in different ways, too: Sociologically, it isn't clear whether this expansion of the urban poor population contributed to a pre-existing revolutionary mood or whether it was the very 'trigger' explaining social unrest at a time when the whole region was already politically in flames. Ecologically, while there was in fact a drought, there is a lack of reflection on the fact that droughts are a recurring feature of Syria's ecology. At minimum an extreme severity of the drought itself and its unique social impact would need to be explained. It subsequently relates the increased intensity of the drought to global climate change and warming, a causal relation similarly difficult to produce evidence for. Last, it doesn't question to which extent environmental degradation emanates from neoliberal agricultural policies which had led to an intensification of land use and soil exhaustion when it may very well have been pricing developments that led to the alleged migration-inducing shortage of resources (Selby et al., 2017). 
This debate on the Syrian drought was the latest in a list of 'climate conflict' and migration scenarios which had started with Sudan's Darfur conflict (Verhoeven, 2011). In the related contemporary global social and ecological crises, (Brand and Wissen, 2017), the Middle East stands out as both the most affected yet least prepared. Most, if not all of these arguments are grounded in the notion of already dysfunctional Middle Eastern and African postcolonial social formations unable to cope with overwhelming demographic and social developments. This fragility is also thought to be caused by the presumed mismanagement and environmental overexploitation by 'native', technologically 'primitive' environmental governance. Creating scarce, violent and hostile imaginaries of the Middle Eastern environment, thus, serves as a pretext for colonial rule in the name of rescuing the environment (Davis and Burke, 2011, p 11). Notoriously insecure and fragile postcolonial states, while trying to emulate colonial rule, rather than managing scarcity, in fact project their insecurities onto an already insecure environment. The overengineering of nature and especially its water resources causes or aggravates pre-existing damage. These social pressures, including demography, are now thought to intensify due to ecological pressures, most importantly anthropogenic global environmental change.

This article offers a different, less pessimistic or dystopian way of incorporating ecology into the analysis of crisis in the Middle East. It starts by revisiting the dual problem of environmental determinism and orientalism. It argues that the role of the postcolonial state as the 'overexploiter' of nature must neither be ignored nor be left to culturalist explanations. Rather, it should be contextualized within the geopolitical, competitive order. While political ecology has paid attention to local and national struggles around ecology, it has yet to introduce this central element of geopolitics more systematically. International Historical Sociology (IHS), in turn, treats nature uncritically along the Cartesian nature/society binary, akin to most conventional social science. There is little reason, however, why it shouldn't adapt political ecology's core argument about the social and political, contingent nature of nature. This includes all forms of energy, notably hydro-carbon resources, as well as water and climate. Above all, this applies to some of the core categories of the discipline of International Relations, such as the 'geo' in politics, including territory, cartography and other manifestations and representations of politicised space. This article closes by mobilising Murray Bookchin's Dialectical Naturalism to offer an open-ended, potentially progressive understanding of 'first' and 'second' (human) nature as a way out of the dual determinisms plaguing most analyses of the contemporary crisis in the Middle East.

\section{From Environmental Orientalism to Environmental Determinism}

The latest debates on 'climate conflict' closes the cycle of a longer-standing tradition of 'environmental orientalism', whereby old debates on the precarious society and environment link up to its securitization. These ecological imaginaries of the Middle East become part of a gloomy dystopian postcolonial vision of the region. Looking more closely at the patterns of postcolonial development, it becomes clear that there is indeed a problem with postcolonial rule and the ways in which it appropriates nature. Intensification of land use by large scale commercial agriculture, settling pastoralists and other mobile populations, the overuse of chemical fertilizers and irrigation technology lead to soil exhaustion, erosion, water scarcity, overgrazing, deforestation, local droughts and other environmental and social damage. Old and new, national and global land and water 'grabs' are another way of looking at this intensification of exploitation (e.g. Antonelli and Tamea, 2015). These are the global successors of more national or regional visions of 'African' and 'Arab' breadbaskets, when the Middle East's environment was still perceived as fertile and plentiful. Shortages, rather than being 
solely caused by climate change or postcolonial developmentalism are also imposed by global markets favouring the economies of scale inherent in large-scale industrial agriculture. This harmful combination in the appropriation of nature is in fact frequently what drives ecologically destructive developments. In other words, it's the presence of exploitable resources, not their absence, or abundance, rather than scarcity, that explains environmental damage as well as the related conflicts (Selby and Hoffmann, 2014). The latest instance of seeing and treating 'nature as an accumulation strategy' (Smith, 2009) are unproductive conservation and carbon schemes and biofuel production.

This is in opposition to the wide spread practice of 'securitizing' the Middle East's nature which is common in the neo-Malthusian literature (Biswas, 2011; Trombetta, 2010). This practice of constructing pristine nature as fascinating wilderness and dangerous threat at the same time, thus, stands in the imperial tradition, inviting interventions intended to save both the natives as well as the environment mostly from themselves. Postcolonial states, once tasked with taking over this role as implants of modernity, are either seen as weak, incapable of handling precarious populations and environments alike, or too strong, over-exploiting resources, implying the superiority of the colonial regime over its successors. In many ways the story about resource appropriating and mismanaging postcolonial states relates to imperialist ecological legacies. First, it is the imperial practices these states emulate that are problematic and ecologically damaging. Second, the imperial legacy is not just historic but also present, especially when looking at donor and investor led policies, especially in agriculture. Third, the postcolonial geopolitical order leaves postcolonial states within a system where appropriating nature is institutionalised as a competitive practice.

Egypt frequently serves as the prime example: A leading member of the Non-Aligned Movement (NAM), it successfully exploited the cold war geopolitical rifts in the region in its pledge to fulfil its hydro-civilisational mission on the Nile. Apart from causing much ecological damage and displacing the native Nubian tribes, Egypt also continues to compete over Nile waters with its upstream co-riparians, above all, Ethiopia. Despite the promised savings from reduced evapotranspiration by storing the water further upstream in higher altitude with lower temperatures, Egypt is fiercely opposed to this change due to the implied loss of control and power. After decades of exercising 'hydro-hegemony' over the Nile valley, Egypt now appears more vulnerable, its arguments more defensive than aggressive or 'greedy' (Cascão, 2008). In fact, it frequently appeals to the international community to help its cause as a matter of 'survival'. Similar observations can be made about the Euphrates and Tigris valleys where Turkey and the various parties involved in Syria and Iraq demonstrate the continued relevance of transboundary water politics for understanding wider geopolitical dynamics, both historical and contemporary (Oktav, 2017). What these examples amply illustrate is that the imperial appropriation of nature has left a legacy in the form of postcolonial states now competing over resources as part of their respective developmental visions. Social development, rather than being 'internal' or just 'economic' is, thus, tightly bound up with the region's geopolitical order, itself a postcolonial legacy. This doesn't mean that every form of competition equals conflict, however, maintaining power and control to the largest degree possible appears to remain imperative. In sum, nature-society relations in the Middle East are, more generally, still part of the imperial legacy and remain geopolitically mediated within a postcolonial regional order.

The problem of environmental orientalism in the Middle East is not merely one of imperial practices, securitization or capitalist appropriation of nature. It is rooted in ecological thought, too. An 
unreflected celebration of a traditional and pristine ecology is similarly based on a de-socialised understanding of nature, identifying a parallel, wishful 'pure' environment, the 'noble savages' or natives are part of. Though 'southern' in origins, its protection is, paradoxically, only achievable by the global north (Lohmann, 1993). Pristine nature, while admirable, if left on its own, is easily lured into self-destruction, or indeed into threatening society at large.

Despite its attraction, nature and society in the Middle East represent a case of fragility and exceptional hardship. The peculiarities of the region mean that social, political and economic development are all held back by inalterable social backwardness, aggravated by its exceptionally hostile nature. Society, while capable and empowered to subjugate nature on a global scale in the West, is reduced to a passive recipient of its largely uncontrollable forces in the Middle East. The arrival of the fossil fuel economy, having promised riches, has paradoxically further added to this misery according to most academic, journalistic and policy 'resource curse' accounts. Though hardship doesn't always and everywhere cause conflict, development in the region is nevertheless disproportionately limited, rather than enabled by the Middle East's precarious environment.

By contrast, Biblical and ancient historical narratives of the Middle East see a productive and lush environment. In fact, the fertile lands of Mesopotamia and Palestine are meant to be the origins of sedentary agriculture, if not human society altogether. To this day, notions of 'Arab' and 'African' breadbaskets coexist uncomfortably with expectations of 'bread riots', modern agriculture is central to food security as much as it is to soil exhaustion. Cultivation, irrigation and agricultural markets are central to any form of rule in the region, in the colonial, the postcolonial, the failed and the 'Islamic' state alike (Eklund et al., 2017).

Environmental orientalism, thus, operates a fragile binary between abundance and scarcity, constantly at risk of collapsing one into the other. The simultaneous richness and deprivation makes the Middle East an 'unnatural nature' and a tension-ridden relationship between the 'precarious' environment and political structures. This 'unnatural nature' used to be expressed only in relation to water, climate and agriculture. Fossil energy, though a more recent discovery, is by no means less disruptive a social force in the Middle East's socio-political development. With some of the region's states having moved from agricultural to fossil fuel producers, the schizophrenic relationship continues to be reproduced. Once a source of abundant wealth (Huber, 2015), oil is now more seen as a curse, if not the ultimate explanation for social and environmental degeneration in general, including the continued neoimperial onslaught on the region (Williams and Le Billon, 2017). Geological riches, once seen as conducive to wealth creation, human progress and development more generally, are now the chief culprit in its degeneration.

However, it's not just the hydro-carbon discoveries themselves that prove to be problematic. Energy transfer routes, usually in the form of pipelines, invite conspiracy theories about the overdetermination of the region's geopolitics. Syria's civil war quickly became a 'Pipelineistan War' (Escobar, 2012; Mas 2017) where the US and Iran not only compete over Syria's resources, but also over East-West transfer routes (Enab Baladi English, 2017) as symbols of a more global power contestation. This central emphasis on hydro-carbons somewhat mirrors arguments about climate change determining social development more generally. In both cases ecological properties impact detrimentally on political structures unable to cope. The crisis in the Middle East and its conflicts are, 
thus, tightly related to the region's ecological features. Transboundary waters, climate change, geology, topography and demography all mix into one rippled nature-society relation. Yet 'society' in this case is not exhausted by local governments, but by external forces, too, all of which share an interest in the region due to its abundant energy supplies, i.e. in its ecological properties thought to be destructive. 'Western' demand for hydrocarbons explains imperial invasions from Iraq to Afghanistan as well as new entrants into the market like China (Yetiv, 2007). It also mirrors the general imperial relationship to the Middle East's nature as destructive for its native environment, while empowering outside imperial forces.

Ultimately the region's ecology explains both the internal contradictions of 'rentier', 'petro' (Kennedy, 2014) or the 'failed' states as well as the preceding and ongoing imperial onslaught based on the inflexible demand from hydro-carbon based capitalist accumulation. Social and ecological damage become mutually reinforcing and irreversible. A natural deterministic and Orientalist understanding of the Middle East offers little hope for escaping the resource, energy, demographic, food, climate and all associated social curses. While the inherent resource and climate determinisms have been extensively criticised more generally (Hulme, 2011), they remain a mainstay of many analyses of the Middle East. An asocial reading of nature and the notion of the Middle East's 'fragile' ecology are continuously reproduced in conjuncture, including by many voices generally critical of a security centred thinking on global crisis.

Long before climate alarmism became fashionable, historical sociological accounts referred to nature as a social force. Natural catastrophes like droughts or epidemics like the plague explain the decline of feudalism (Herlihy, 1997) and the subsequent colonial expansions. In the Middle East, Karl Witfogel has explained the "Oriental Empire's" high degree of centralisation compared to European fragmentation with reference to its arid climate in need for large scale irrigation systems, which, in turn, require centralised political control (Witfogel, 1957). More recently, the petro-states (Karl, 1997), Western quests for 'valorisation' of territory (Colas \& Pozo, 2011) construct a strong relation between social development and the 'environment'. Given how much causal significance some historical sociological work assigns to nature, from fossil fuel to territory, there is surprisingly little explicit reflection on what 'nature' actually constitutes ontologically. Bio-physical 'facts' like droughts, epidemics and, more recently, climate change, are introduced in fairly conventional and unreflected ways. This is especially surprising for historical materialist work, given the wealth of Marxist thinking on ecology (e.g. Foster, 2000). 'Oil', for example, remains a playball of Great Power politics and as far as the Middle East is concerned a quantity determining the speed and nature of the hegemonic transition (Bromley, 1994, p 76f). Thus, it seems that these views maintain the notion of nature as external to society, an asocial quantity to be valorised, usually in competitive, conflictual ways. Energy, oil, water, resources and nature more generally remain ontologically asocial. By contrast, the current argument suggests that ecology is not only situated within social relations and class struggles, but that it is in fact a social product, or rather an integral part of historically specific social relations (Huber, 2011, p 44). What this article suggests, therefore, is that historical sociology and especially Marxist scholarship on the Middle East would benefit from a greater recognition of political ecological thought. As Foster has pointed out (1999), it is surprising that not more literature engages with it given there is an abundance of systematic insights into environmental problems by much of classical sociological thought. The appropriation of hydrocarbons and other elements in nature was directly colonial, uprooting 'traditional' nature-society relations. It was the postcolonial state emulating or even 
aggravating these colonial practices within a geopolitically competitive environment. At the same time, these old/new practices of post/colonial appropriation of nature were enabled and catalysed by the acceleration of international homogenisation (Mitchell, 2002). The political economy of global ecology produced a technocratic standardisation, modernisation and appropriation of resources, which, remain, however, mediated by a system that is geopolitically fractured. Nowhere is this more obvious than in the Middle East. Yet by constantly pointing out the global nature of this process of appropriation, both social ecologists but also Marxists underestimate the importance of multiplicity. It problematises a homogenised process of exploitation, which is, in fact, at the same time fractured. It is intensified and multiplied by the competitive state developmentalism that characterises the Middle East. Hence, multiplicity and fracture and the social relations they generate, as reflected by IHS and especially a historicist understanding of geopolitics, is missing from the conventional political ecology narrative. Political Ecology, rather than focussing on an amorphous 'global' capitalism and its universal appropriation of nature, would benefit from greater historical specificity and especially a direct reflection on how fracture or geopolitics co-determines this process. In sum, historical sociology lacks an in-depth reflection of its ecological foundations, while political ecology lacks awareness of the central role of fracture, multiplicity and the 'geo', socially understood, in its politics.

This mutual ignorance seems odd. Sharing some intellectual origins, political ecology and historical sociology have much in common, most importantly the emphasis on historicising social power relations. Historical sociology's lacking understanding of nature, matter and energy is, therefore, something that could easily be overcome using political ecology approaches, or in fact the foundational Marxist work on nature and energy as a social relation. Conversely, geopolitics, 'multiplicity', fracture or 'the international' is less clearly defined and likely requires political ecologists to enter the debates on historical sociology of international relations more fully.

While there is a flurry of thinking on the question of geopolitics in historical sociology, the reverse is true for political ecology. Here, the international dimensions area rarely made explicit. When it gets to international relations, there is little explicit thinking beyond the dominant realist and liberal traditions in resource politics. Assumptions about competition, conflict, or, cooperative sharing of, say, transboundary water resources are implicitly accepted by political ecologists. Their work tends to focus on conflict patterns on smaller, local or maybe national scales. If openly and directly reflected, Marxist political ecology approaches tend to focus on the inequalities of global trade, loosely related to a world systems tradition. Clark and Foster's (2009) argument about the unequal relations of trade demonstrates how the exploitation of nature and, in this case, the transfer of nutrients from the global south to the north is representative of the geopolitical differentiation and hierarchical international relations. It surely is, however, pointing out this truism doesn't reflect on how inter-state relations may alter the social substance of nature.

\section{Dialectical Naturalism the forward?}

The current argument intervenes precisely at this juncture of geopolitics and ecology, developing a more explicit notion of a geo-political ecology. This assumes, first, that the ontology of 'geo' is neither just enshrined in the material or biophysical constitution of 'nature' as Cartesian traditional geopolitics would argue. Second, it also denies the purely 'discursive' and representative meaning of territory as articulated by much of the critical geopolitics tradition (e.g. Atkinson and Dodds, 2002). Instead, a critical realist understanding of nature as a material ontology which only acquires meaning through its 
social articulation and appropriation is applied. Geopolitics, is, thus, best understood as a 'geopolitical social' (Cowen and Smith, 2009), rather than either purely a Cartesian-material or ideational category. Territory, space and ecology more generally, while biophysically manifest, acquire different meanings not once, but constantly, through different historically specific appropriations and political understandings nature. The invention of the combustion engine, and especially the political economic construction of a post-war hydro-carbon based international order has, thus, socio-materially produced the contemporary understanding of the Middle East as a geopolitically sensitive space. This explains continued interventions up to the current crisis. 'Nature', including the mainstay of 'geo', thus, changes its social meaning in line with global regimes of social reproduction. It is, however, also not entirely reducible onto-political legacies, starting from Malthusian dystopic-mechanistic visions of the Middle Eastern environment to cold war understandings of geopolitics, continue to be reproduced intellectually. The 're'-emergence of cold war thinking in the wake of the Ukraine crisis serves as a powerful reminder in this regard. And while there is an important space for critical geopolitics in the project of dismantling these dominant ontologies, its suggestion to reduce nature to discourse has serious shortcomings.

\section{Dialectical Naturalism}

What is at stake then, is to formulate the theoretical foundations for a 'geo-political' ecology in between the materiality of and the discourse on nature. A closer reading of Marx as formulated by Bellamy Foster (2000) and others identifies the common ground between political ecology and historical sociology. Central to this project of 'resurrecting' Marx's and Engel's ecological thoughts is the concept of a universal, social metabolism relating to all maintenance of life. Marxist ecology is concerned with understanding the crisis, the metabolic rift under capitalism, as a materialist-dialectical process. Through the application of energy, or labour, production and human social reproduction enters into this unified metabolic relationship with 'nature'. This 'universal metabolism' where humans are part of a unity with non-human nature, is ruptured by a process of separating the inorganic conditions of humanity's social reproduction from the rest of life and humans' "active" existence through the introduction of wage labour relations (Marx, 1973; 427). This separation is preceded and enabled ontologically by the Cartesian nature/society divide, which also gave rise to the tradition of geopolitics. Under the conditions of capitalist reproduction, this then turns into a metabolic rift, which is both social and ecological. Ecological crisis is, therefore, seen as a material dimension of a holistic process of social alienation, induced by the introduction of wage labour relations, alienating humans from their 'active' material reproduction, including nature. Ecological processes and crises, including those in the contemporary Middle East, are therefore intrinsically social. While humanity's engagement with nature may well be transhistorical, the natures that are produced in the process are still specific. Materially, ideationally, politically, but also geo-politically differentiated. Not population growth, hydro-carbon discoveries or the effects of climate change per se, but the social conditions of capitalist reproduction within which these technological and ecological phenomena occur, generate separate and alienated forms of 'nature' and 'society'. This includes their discursive and material social production.

This specifies the concrete historical conditions under which a specific form of geopolitics as a social practice emerges. What is suggested here, therefore is to denaturalize this historical process of dialectically producing nature-society relations, including those supposedly imposed by topographic, territorial, cartographic or environmental imperatives. What the suggested nature-society dialectics 
offers is an understanding of the concrete reality of society and the world as a "complex, heterogeneous and changing totality" (Foster, 2016).

Murray Bookchin, develops this 'dialectical naturalism' in his 'Ecology of Freedom' (Bookchin 1991). He argues in favour of the inseparability of 'man' or 'reason' and 'nature'. First, all human, conscious development is deeply related to the ecological conditions of its emergence. Only through this 'rationality' and human subjectivity is the 'object' of nature generated intellectually as a central ontology. The 'production of nature by man' is, thus, not just at the same time also a production of man by nature, but a mutually conditioned, historical-dialectical process. It is, therefore, also not just material, bio-physical or even just specific to capitalist modernity, but deeply conditioned by the development of spatio-temporally dynamic and specific forms of human reasoning.

This dynamic, historical evolution of human reasoning, thus, generates specific ontologies of nature as bases for different forms of ecological exploitation and associated social power relations more generally. In this case, the hierarchical Cartesian ontology enables specific forms of exploitation under capitalism (Bookchin, 1982) and is an enabler for the hydro-carbon economy. In Bookchin's antihierarchical thinking, the privileging of humans over non-humans is one of many expressions of hierarchical relationships, from class to gender, all of which are maintained within capitalism and, crucially, through the institutions of the state. Thus, dissolving relationships of domination, both of 'man over man', 'men over women' and 'humanity over nature', requires, first, a deeper rethinking of society along an open-ended dialectic. Allowing for the formulation of future alternatives, dissolving, or at least bypassing the power structures responsible for maintaining the hierarchical relations is, of course, the state, which strategically deploys notions of 'scarcity' as a means of social control. While this gets us out of the neo-Malthusian alarmism as well as other forms of environmental determinism, it sets the bar nevertheless quite high in terms of the conditions for social change. Still, pointing out the historical specificity of centralised states, their central role in resource development and their permeability is pivotal. Not least since this observation especially applies to the postcolonial state.

As a way forward dialectical naturalism asks for a restorative relation re-harmonizing relations, overcoming a hierarchical divide without collapsing it into the crude monism of 'Deep Ecologists' akin to the 'pristine nature(s)' associated with Orientalism. This non-hierarchical path of transformation is mediated through education, allowing for the full self-realization of 'second' (human) nature's rational potential. To be precise, this should not be read as a radically anti-modernist regression towards a romanticised life with and in nature. Infrastructure and technology are part and parcel of this progressive dialectical relation between nature and human reason. A belief in human creativity replaces ill-fated liberal linear or realist cooperation and conflict teleologies alike. At the heart of this positive vision lies the ambition to realise ecological restoration within an anti-hierarchical, postscarcity society (Bookchin, 1971).

The underlying thinking of dialectical naturalism engages the question of the nature/society divide beyond polar opposites of an undifferentiated 'whole' or a strictly divided ontology, but as part of a wider social totality encompassing all social relations (Brincat and Gerber, 2015). This includes all relations to its social-geophysical environment as well as other human communities. Hence, the same dialectics applies to the relationship between (neo)classical forms of geopolitics (Haverluk et al., 2014) and its critics, whereby a 'purist' position on either end would be reductionist. This constitutes a 
powerful advance over either 'deep' ecologist, or 'monist' accounts, as it accounts for the real life abstraction of humanity from the rest of nature.

\section{Postcolonial Development and Dialectical Naturalism}

This dialectic has long been reflected in the tension between the representations of the Middle East as 'natural' riches vis-à-vis those that accentuate its 'scarce' and brutal nature. In many ways, this contradictory imagination was revived in the concept of the petro- or rentier state (Beblawi and Luciani, 2015). Bathing in the riches of oil revenues provides little incentive to innovate, generating a uniquely corrupt social formation. Initially, these states do well from the proceeds of hydrocarbon extraction, catering for the continuously increased demand the global political economy produces. This carbon capitalism (Di Muzio, 2015), avoids any fiscal policies requiring political support. It protects authoritarian clientelist regimes at a home while being geo-politically protected by Western hegemony (Vitalis, 2007). A typical outcome is an above average level of cronyism and autocracy, fuelled by the recycling of petro-dollars in the arms trade. Hydro-carbon revenues, thus, offer a political base far away from Western ideals of democracy. Similarly, they also provide no incentive for political or socioeconomic change or development. Cheap casual labour from around the third world is used for economic expansion into the services sector, mostly real estate and logistics, all of which are, however, catering for the recycling of oil revenues. Typically, this 'model' is applied to the Gulf states, or the Arab oil producing member states of OPEC. Conventionally, however, it has come to represent the region as a whole (Hanieh, 2016).

As the above has made clear, both the concept of the rentier economy as well as that of climate conflict remain true to the tradition of environmental determinism and orientalism alike. Dialectical naturalism, by contrast, offers a way forward. First and foremost analytically but, secondly, also politically in that it interrogates the historical sociology of nature-society relations and the role of modern, national postcolonial rule in particular. Most political formations in the Middle East's 'scarce' environment have carried through with the colonial mission of subjugating nature after the Empires' departure. From Turkey's Ataturk Dam to Egypt's Aswan Dam. Hence, as with oil, extraction of wealth and energy, in this case in the form of water and soil riches, is still carried out under the auspices of a global hydro-carbon regime, including that of the cold war. As with the rentier states, these hydrocivilisational missions are carried out by postcolonial formations within geopolitical environments that remain not only in a competitive position towards one another, but also in an ongoing pathological position towards their own identity, which frequently includes, above all, their territorial integrity as well as ethno-linguistic homogeneity. Being competitive and ego-anxious, yet protected by a hegemonic umbrella, large scale engineering projects from mega-dams to canals still play a role in the hydro-demographic engineering of societies and, by extension, the reproduction of social power structures and hierarchies.

More recently, however, it was, surprisingly, those states supposedly most determined by their geological riches, the gulf states that started transforming, embracing the role of technology and progressive thinking by investing in Green Growth projects (Asif, 2016; Reiche, 2010). From energy, water, agriculture and urban growth all seem to serve as a proto-example of techno-developmentalism as an intrinsic part of the region's ecology. Using solar powered desalination plants and other forms of large scale ecological engineering, the 'Green' initiatives, while initially serving as yet another 
investment vehicle for recycling oil revenues, may well form the eco-material basis for an alternative social order in the Gulf. Though not outright dismantling hierarchical power structures, these initiatives of the notorious petro economies serve to undermine assumptions about path dependency and structural determination inherent in the rentier state argument.

What 'green' or sustainable growth in general doesn't do, however, is to overcome the process of alienation of nature from humanity. The introduction of 'green' liberal capitalism which reformulates, rather than overcomes these processes of alienation cannot redeem the original sin. Instead of entering abstract nature into a kinetic economic process, new 'green' environmental 'goods' and (especially) 'bads'" (Smith 2007, 20) are, even in their 'preserved' and unproductive state, tradable commodities, reifying the ontological separation and abstracting nature from the social totality none the less.

There are, however, other forms of re-formulating nature-society relations that undermine the orientalist environmental determinisms. The question of territorial and population control and environmental degradation is frequently associated with agriculture and food production. Already for Marx, geophysically, the metabolic rift is observable first and foremost in soil exhaustion and depletion as a result of over-fertilization in industrial agriculture. In the Syrian civil war, the fertile, high yielding river valleys along the Euphrates and its tributaries, which also includes access to its hydroelectric plants became a central strategic asset in the war, not least due to the high yields they generate. Kurdish held areas, by contrast, still mostly rely on pump irrigation and are left with a legacy of internal colonialism, having only produced food staples as part of a Baathist state strategy of marginalization and forced migration. This creates potential issues with food security, which also carries a strategic dimension in a war economy. In reaction to the embargo and to overcome the exhaustion of soils brought on by decades of chemically fertilized wheat production by the regime, the local administration of the northern Syrian confederation, or 'Rojava' (West Kurdistan), launched a plan to expand local subsistence production using organic fertilizers from local waste (Rojava Plan Wiki 2016). The production of organic fertilizers is the first project implementing organic self-sufficient production operationalizing Bookchin's principles of 'Social Ecology'. The plan has identified a need for fertilizers that can be met through creating a system of collecting local organic waste, processing it, and redistributing it to agricultural cooperatives (Plan C 2016). The introduction of the fertilizer project not only implements organic agriculture and helps overcoming shortages generated by a history of deliberate underdevelopment. It is hoped that this meets food insecurity issues due to the lack of chemical fertilizers but also provides the ground for diversifying agriculture in the future, with the declared aim of 'food sovereignty' (Patel 2009). Politically, it identifies education as a key institution in the transformation intrinsic to the political project of 'democratic confederalism' (Kurdish Question 2016).

As the experience of Rojava shows, it is not just the process of decision making itself and the everyday politics of maintaining rule in the provision of 'soft' public services such as education that are openly political and social in nature. Similarly, 'hard' or physical infrastructures do not just provide public goods, such as food, water, shelter, health and energy, all of which are intrinsically social, or 'lively' (Amin 2014). They are created in specific geopolitical circumstances and produce environment(s) that are similarly geopolitically relevant. Just like the maintenance of certain rural and urban property regimes imply the installation of corresponding physical structures, so does any project of socio- 
political change demand adaptation of practices of geo-spatial re-modelling. And though this intention of moving towards a social ecology may become part of a successful challenge to dominant power (infra)structures, it also bears the risk of producing new social contradictions and (geo)political vulnerabilities.

\section{Conclusion: Towards a Geo-Political Ecology}

From Prince Charles to the Pentagon, from Syria to Sudan, the wisdom about ongoing 'climate conflicts', the looming threats of climate refugees and the coming age of water wars, replacing oil wars as the new environmental 'curse' paint a chilling picture of the Middle East as a perpetually conflict prone region. All of them, however, put the region's precarious environment at the centre of explaining both its historic and contemporary crises. This article identified these trends as the re-incarnation of the imperial practice of Environmental Orientalism, geared towards maintaining a hierarchy between an environmentally competent West and the age-old Middle Eastern inability and unwillingness to 'manage' its lush nature in a sustainable and stable fashion. Political ecologists have helped understanding the problematic local conditions under which both conflicts and imperial environmental orientalist imaginations are reproduced. As this article has demonstrated, there are important geopolitical dimensions, understood here as the 'geopolitical social', in this process of socially producing nature, political ecologists have yet to fully accommodate. In line with this geopolitical analysis, this article has identified the institutions of the postcolonial state and its geo-political location within a competitive environment as one of the core reasons behind the Middle East's ongoing socioecological crises. Just like energy, matter and nature itself, it argues that only a historical sociological understanding of all of these categories can offer an improved understanding of the current crises and their environmental dimensions. In doing so, it suggests a greater dialogue between political ecology and historical sociology. While missing this geopolitical dimension, political ecology offers a historicism of nature that can offer an important building block for overcoming environmental determinisms of all sorts, including those implicit in much historical sociological work. Here Cartesian ontologies of nature are still engaged uncritically, yet in causally highly significant ways. It is not just the unreflected understanding of nature itself, but the way in which it is deployed as causal explanations that gives rise to this call for an exchange.

The critique of conventional understandings of nature, its securitization and commodification is well rehearsed and doesn't need to be repeated here. In response, this article doesn't advocate a 'deep ecology' as it arguably reproduces the problematic Cartesian divisions underlying many environmental problems. Instead, it proposes a historical sociology that understands ecology dialectically, as an intrinsically social category. In order to do so, it suggests a dialectical naturalism broadly based on the work of Murray Bookchin. Here, nature is neither entirely separate from nor entirely identical with humanity, but rather enters a dialectical historically dynamic relationship with 'second' or human nature. Second, it calls for a historicisation of this dialectical naturalism across the colonial and postcolonial divide in the Middle East. The global, geopolitical and local conditions under which the nature/society complex is socially reproduced exposes the postcolonial state as central for understanding the historical constitution of socio-ecological crises but also for formulating alternatives. Finally, the article argued in favour of more geo-political ecology in historical sociology and vice versa. 
This may not be solely applicable to the Middle East, but it is here that we see the greatest and possibly most detrimental impact of Environmental Orientalism as a deeply entrenched academic practice. Just as Alexander Wend famously revolutionised the discipline of International Relations with the somewhat modest revelation that 'anarchy is what states make of it' (Wendt, 1992) the same can be said about the orientalist ontology of nature in the Middle East and beyond.

\section{REFERENCES}

Amin, A. (2014). Lively infrastructure. Theory, Culture \& Society 31(7-8): 137-161.

Antonelli, M., \& Tamea, S. (2015). Food-water security and virtual water trade in the Middle East and North Africa. International Journal of Water Resources Development, 31(3), 326-342.

Asif, M. (2016). Growth and sustainability trends in the buildings sector in the GCC region with particular reference to the KSA and UAE. Renewable and Sustainable Energy Reviews, 55, 1267-1273.

Atkinson, D., \& Dodds, K. (Eds.). (2002). Geopolitical traditions: Critical histories of a century of geopolitical thought. Routledge, London.

Beblawi, H., \& Luciani, G. (Eds.). (2015). The rentier state. Routledge, London.

Biswas, N. R. (2011). Is the environment a security threat? Environmental security beyond securitization. International Affairs Review, 20(1), 1.

Bookchin, M. (1982). The ecology of freedom: The emergence and dissolution of hierarchy. Palo Alto, CA: Cheshire Books.

Brand, U., \& Wissen, M. (2017). Social-Ecological Transformation. The International Encyclopedia of Geography. Online First

Bromley, S. (1994). Rethinking Middle East Politics. Austin: University of Texas Press.

Cascão, A. E. (2008). Ethiopia-challenges to Egyptian hegemony in the Nile Basin. Water Policy, 10(S2), 13-28.

Clark, B., \& Foster, J. B. (2009). Ecological imperialism and the global metabolic rift: Unequal exchange and the guano/nitrates trade. International Journal of Comparative Sociology, 50(3-4), 311334.

Colás, A., \& Pozo, G. (2011). The value of territory: Towards a Marxist geopolitics. Geopolitics, 16(1), 211-220.

Cowen, D., \& Smith, N. (2009). After geopolitics? From the geopolitical social to geoeconomics. Antipode, 41(1), 22-48. 
Davis, D. K., \& Burke, E. (2011). Environmental Imaginaries of the Middle East and North Africa. Ohio University Press.

Di Muzio, T. (2015). Carbon Capitalism. Energy, Social Reproduction and World Order. Rowman \& Littlefield International.

Eklund, L., Degerald, M., Brandt, M., Prishchepov, A. V., \& Pilesjö, P. (2017). “How conflict affects land use: agricultural activity in areas seized by the Islamic State". Environmental Research Letters, 12(5), 054004.

Enab Baladi English (2017) 'Gold is under the Dunes. Many Countries Craving for the Syrian Badia', Enab Baladi English, July 18, 2017, http://english.enabbaladi.net/archives/2017/07/gold-dunesmany-countries-craving-syrian-badia/ (accessed June 22, 2017)

Escobar, P. (2012). Syria's Pipelineistan War, Al Jazeera Opinion, August 6, 2012, http://www.aljazeera.com/indepth/opinion/2012/08/201285133440424621.html (accessed June 7, 2017)

Foster, J. B. (1999). Marx's theory of metabolic rift: classical foundations for environmental sociology. American journal of sociology, 105(2), 366-405.

Foster, J. B. (2000). Marx's ecology: Materialism and nature. New York: NYU Press.

Gleick, P. H. (2014). Water, drought, climate change, and conflict in Syria. Weather, Climate, and Society, 6(3), 331-340.

Hanieh, A. (2016). Capitalism and class in the Gulf Arab states. Springer.

Haverluk, T. W., Beauchemin, K. M., \& Mueller, B. A. (2014). The three critical flaws of critical geopolitics: Towards a neo-classical geopolitics. Geopolitics, 19(1), 19-39.

Herlihy, D. (1997). The Black Death and the transformation of the West. Harvard University Press.

Huber, M. T. (2011). Oil, life, and the fetishism of geopolitics. Capitalism Nature Socialism, 22(3), 3248.

Huber, M. (2015). "Energy and Social Power - From political ecology to the ecology of politics". Perreault, Tom, Gavin Bridge, and James McCarthy, eds. The Routledge handbook of political ecology. London: Routledge, pp 481-492.

Hulme, M. (2011). "Reducing the future to climate: a story of climate determinism and reductionism". Osiris, 26(1), 245-266.

Karl, T. L. (1997). The paradox of plenty: Oil booms and petro-states (Vol. 26). Univ of California Press. 
Kelley, C. P., Mohtadi, S., Cane, M. A., Seager, R., \& Kushnir, Y. (2015). Climate change in the Fertile Crescent and implications of the recent Syrian drought. Proceedings of the National Academy of Sciences, 112(11), 3241-3246.

Kelly, P. (2006). A critique of critical geopolitics. Geopolitics, 11(1), 24-53.

Kennedy, E. (2014) "From Petro-States to 'new realities': Perspectives on the Geographies of oil." Geography Compass 8 (4), 262-276.

Kurdish Question (2016): Syrian Kurdish Region Witnessing Campaign of 'Organic Agriculture in Rojava', available at: http://www.kurdishquestion.com/article/3206-syrian-kurdish-regionwitnessing-campaign-of-organic-agriculture-in-rojava (accessed 04/06/2016)

Lohmann, L. (1993). Green orientalism. The Corner House, 1 November 1993 http://www.thecornerhouse.org.uk/resource/green-orientialism (accessed June 11, 2017)

Mas, C. (2017). Syria: A Nonsensical 'Pipeline-Triggered' War Theory Debunked. Kurultay.fr 16 January 2017, available at: https://kurultay.fr/blog/?p=1103 (accessed July 6, 2017).

Mitchell, T. (2002). Rule of experts: Egypt, techno-politics, modernity. Berkeley: University of California Press.

Plan C (2016): Feed the Revolution: An Interview with Rojava Plan, available at: http://www.weareplanc.org/blog/feed-the-revolution-an-interview-with-rojava-plan/ (accessed 07.07.2016)

Oktav, Ö. Z. (2017). Turkey's water policy in the Euphrates-Tigris basin. In Environmental change and human security in Africa and the Middle East (pp. 239-255). Springer, Berlin.

Patel, R. (2009). Food sovereignty. The Journal of Peasant Studies, 36(3), 663-706.

Reiche, D. (2010). Renewable energy policies in the Gulf countries: A case study of the carbon-neutral "Masdar City" in Abu Dhabi. Energy Policy, 38(1), 378-382.

Rojava Plan Wiki (2016): Fertilizer Project, available at:

http://wiki.rojavaplan.com/index.php?title=Projects/Fertilizer (accessed 07.07.2016)

Selby, J., Dahi, O. S., Fröhlich, C., \& Hulme, M. (2017). Climate change and the Syrian civil war revisited. Political Geography, 60, 232-244.

Selby, J. \& Hulme, M. (2015). 'Is climate change really to blame for Syria's civil war?' The Guardian Comment Is Free, 29 November 2015, available at: https://www.theguardian.com/commentisfree/2015/nov/29/climate-change-syria-civil-war-princecharles (accessed June 10, 2017) 
Selby, J., \& Hoffmann, C. (2014). Beyond scarcity: rethinking water, climate change and conflict in the Sudans. Global Environmental Change, 29, 360-370.

Smith, N. (2009). Nature as accumulation strategy. Socialist register, 43(43).

Trombetta, M. J. (2010). Rethinking the Securitization of the Environment. Securitization Theory, Abingdon: Routledge, 135-149.

Verhoeven, H. (2011). Climate Change, Conflict and Development in Sudan: Global Neo-Malthusian Narratives and Local Power Struggles. Development and Change, 42(3), 679-707.

Williams, A., \& Le Billon, P. (Eds.). (2017). Corruption, Natural Resources and Development: From Resource Curse to Political Ecology. Edward Elgar Publishing.

Vitalis, R. (2007). America's kingdom: Mythmaking on the Saudi oil frontier. Stanford University Press.

Wendt, A. (1992). Anarchy is what states make of it: the social construction of power politics. International organization, 46(2), 391-425.

Wittfogel, K. A. (1956). Oriental despotism: A comparative study of total power. New Haven and London: Yale University Press

Yetiv, Steve A., and Chunlong Lu. (2007) "China, global energy, and the Middle East." The Middle East Journal 61(2): 199-218. 